\title{
Use of Complementary and Alternative Medicine with Osteo- arthritis Patients
}

\author{
Şefika Dilek GÜVEN ${ }^{1 *}$ (D) and Ayla ÜNSAL ${ }^{2}$ \\ ${ }^{1}$ Nursing Department, Faculty of Semra ve Vefa Küçük Health Science, Nevşehir Haci Bektaş Veli University, \\ Nevşehir, Turkey \\ ${ }^{2}$ Nursing Department, Faculty of Health Science, Ahi Evran University, Kirşehir, Turkey
}

*Corresponding author: Şefika Dilek GÜVEN, PhD, Assistant Professor, Nursing Department, Faculty of Semra ve Vefa Küçük Health Science, Nevşehir Haci Bektaş Veli University, Nevşehir, Turkey, Tel: 9038-4215-2380/23004, Fax: 90384215-2300

\begin{abstract}
Introduction: The treatment of Osteoarthritis (OA) includes pharmacologic and non-pharmacologic methods. In getting no response to traditional medical treatment it causes the use of effective and confident treatment of $O A$ and as a result patients tend to use Complementary and Alternative Medicine (CAM).

Methods: This study which is a descriptive type has been done on patients with $\mathrm{OA}$ in case of defining the use of CAM. This study has been done on patients who applied to physical therapy polyclinics. The sample of the study covers 77 patients with OA. In accumulating the data questionnaire form has been used. The data were evaluated by computer, percentage and chi-square.

Results: In our study it has been found out that $23.4 \%$ of OA patients used CAM. In applying CAM methods it has been determined that $66.6 \%$ used massage, $38.8 \%$ used diet and $33 \%$ used music. $83.3 \%$ of patients using CAM with the notice of a doctor whereas $16.7 \%$ without it. Maritual status, birth place and income conditions in relation with the use of CAM have been statistically significant $(p<0.05)$, gender, age, educational status and occupation in relation with the usage of CAM have been statistically insignificant $(p<0.05)$.

Conclusions: At physical therapy polyclinics working nurses when receiving in service training CAM methods should be added to make them well equipped. It is also suggested that the staff working in health departments should follow researches based on facts including CAM methods and its effects.
\end{abstract}

\section{Keywords}

Complementary and alternative medicine, Osteoarthritis, Nursing

\section{Introduction}

Osteoarthritis (OA) is a joint disease which is seen part of the rising age in people, which results in aching and disability and that's why it has got a negative effect on the quality of life [1]. With the rising number of the elder people in the population (society) OA has become a significant health problem. In the USA OA has been seen $3 \%$ among people aged 30 and over [2], people aged 45 and over have been seen between 19.2\%$27.8 \%$ [3]. In a study made in Turkey OA prevalence has been reported to be $14.8 \%$ [4].

The treatment of OA includes pharmacologic and non-pharmacologic methods. In getting no response to traditional medical treatment it causes the use of effective and confident treatment of $O A$ and as a result patients tend to use CAM. In USA, among the patients who complain about arthritis rank the sixth place. It is estimated that among those patients having OA the percentage is quite high [5].

As a result of rising concern of CAM among individuals the need of CAM has been tried to be fulfilled by people apart from health staff [6]. The resulting of this condition, nurses whose aims are to supply the health needs of human beings the role of CAM has become compulsory. In this direction the usage of CAM's in nursing intervention development, effective strategy determination and guidance of individuals concerning the usage of CAM effectively and correctly are expected [7]. 


\section{Material and Methods}

This is descriptive study on patients admitted to the physical therapy polyclinics of the Nevşehir i. Şevki Atasagun State Hospital, Nevşehir, Turkey in 2015.

The subjects of this study were 77 patients with OA admitted to the physical therapy polyclinics. Each participating patient was administered a survey questionnaire, filled out through a face-to-face interview in the physical therapy polyclinics. Before performing this study approval was obtained by the Directory of Health Services of the Province of Nevşehir and by the patients. The pilot test involved the researcher distributing the questionnaire to ten people with $\mathrm{OA}$ at state hospital.

The patients were administered in clinical wards a survey questionnaire consisting of 23 questions; 7 of which were on demographics, 9 on the OA records, and the remaining 7 on whether, how and why they have used CAM.

A chi-square test was used to chart comparisons between demographic groups. All variables are included as categorical in this analysis. Univariate and multivariate logistic regression analysis was applied to determine which factors are determinants of CAM use. The variables statistical significant in the chi-square test (gender, age, maritual status, educational status, birthplace, income and occupation) was applied. The data were recorded and analyzed by using computer.

Before starting the research, the patients were informed about the purpose of the research and the data collection tools to be used and their approvals were obtained.

\section{Results}

We included 77 patients, of whom $79.2 \%$ were women, $51.9 \%$ over the age of $60,53.2 \%$ married, $48.1 \%$ retired, $32.5 \%$ high school graduates, $51.9 \%$ living in the city and $61.0 \%$ had a middle income in the age group (Table 1).

It has been designated that $23.4 \%$ of OA patients have been using CAM. $66.6 \%$ of CAM users have been using the massage method, $83.3 \%$ have preferred it to treat the disease, $83.3 \%$ have shared it with the doctor, $44.4 \%$ have trusted the effectiveness of CAM, $61.1 \%$ have had the source of knowledge from TV/radio and $55.5 \%$ have used it by the recommendation of the doctor (Table 2).

Birth place and income conditions in relation with the use of CAM have been statistically significant $(p<$ $0.05)$, maritual status, gender, age, educational status and occupation in relation with the usage of CAM have been statistically insignificant $(p<0.05)$ (Table 3$)$.

\section{Discussion}

The results of most of the studies on patients with OA show that most patients are women [4]. In this study $79.2 \%$ of women made the number of patients. The reason why OA is more seen among women can be explained by their sex hormones [2]. The result of this study which supports other studies; the nurses should determine the changeable risk factors of women with $\mathrm{OA}$ and should also plan and apply nursing intervention in order to eliminate the risk factors.

It has been stated that with the age the OA prevalence has been rising $[3,8]$. In this study $51.9 \%$ of patients with OA were at the age 60 and over.

Table 1: Demographic factors of patients $(N=77)$.

\begin{tabular}{|c|c|c|c|c|c|}
\hline \multicolumn{2}{|l|}{ Variables } & \multirow{2}{*}{$\begin{array}{l}\text { Frequency (\%) } \\
61(79.2) \\
16(20.8)\end{array}$} & \multicolumn{2}{|l|}{ Variables } & \multirow{2}{*}{$\begin{array}{l}\text { Frequency (\%) } \\
42(53.2) \\
3(3.9) \\
32(42.9)\end{array}$} \\
\hline Gender & $\begin{array}{l}\text { Women } \\
\text { Men }\end{array}$ & & Maritual Status & $\begin{array}{l}\text { Married } \\
\text { Bachelor } \\
\text { Widowed }\end{array}$ & \\
\hline Age Group & $\begin{array}{l}\text { Under } 30 \\
30-39 \\
40-49 \\
50-59 \\
\text { Over } 60\end{array}$ & $\begin{array}{l}2(2.6) \\
5(6.5) \\
7(9.1) \\
23(29.9) \\
40(51.9)\end{array}$ & Educational Status & $\begin{array}{l}\text { Illiterate } \\
\text { Literate } \\
\text { Primary school } \\
\text { High school } \\
\text { Graduate }\end{array}$ & $\begin{array}{l}5(6.5) \\
37(48.1) \\
4(5.2) \\
25(32.5) \\
6(7.8)\end{array}$ \\
\hline Place of Birth & $\begin{array}{l}\text { City } \\
\text { Town } \\
\text { Small Town } \\
\text { Village }\end{array}$ & $\begin{array}{l}13(16.9) \\
22(28.6) \\
15(19.5) \\
27(35.1)\end{array}$ & Occupation & $\begin{array}{l}\text { Retired } \\
\text { Government } \\
\text { Official worker } \\
\text { Housewife }\end{array}$ & $\begin{array}{l}37(48.1) \\
8(10.4) \\
4(5.2) \\
28(36.4)\end{array}$ \\
\hline Home & $\begin{array}{l}\text { City } \\
\text { Town } \\
\text { Small Town } \\
\text { Village }\end{array}$ & $\begin{array}{l}40(51.9) \\
29(37.7) \\
6(7.8) \\
2(2.6)\end{array}$ & Income & $\begin{array}{l}\text { Low } \\
\text { Middle } \\
\text { High }\end{array}$ & $\begin{array}{l}21(27.3) \\
47(61.0) \\
9(11.7)\end{array}$ \\
\hline
\end{tabular}


Table 2: Distribution of patients using CAM $(\mathrm{N}=77)$.

\begin{tabular}{|c|c|c|}
\hline \multicolumn{2}{|l|}{ Factors } & \multirow{2}{*}{\begin{tabular}{|l} 
Frequency (\%) \\
$18(23.4)$ \\
$59(76.6)$
\end{tabular}} \\
\hline CAM Usage (n:77) & $\begin{array}{l}\text { Users } \\
\text { Non-users }\end{array}$ & \\
\hline Method of CAM usage* (n:18) & $\begin{array}{l}\text { Massage } \\
\text { Diet } \\
\text { Music } \\
\text { Herbs } \\
\text { Acupuncture }\end{array}$ & $\begin{array}{l}12(66.6) \\
7(38.8) \\
6(33.3) \\
3(16.6) \\
2(11.1)\end{array}$ \\
\hline Resoans for CAM usage* (n:18) & $\begin{array}{l}\text { Treatment of the disease } \\
\text { Getting worse } \\
\text { Relief the pains } \\
\text { Relief the worries } \\
\text { Physical comfort } \\
\text { No other remedy } \\
\text { Getting over the disease } \\
\text { Lack of financial condition } \\
\text { Last remedy/last hope } \\
\text { Curious } \\
\text { Lessen the side-effects of medicine taken } \\
\text { having done all the best } \\
\text { Not happy with the treatment } \\
\text { Nurse recommendation } \\
\text { Doctor recommendation }\end{array}$ & $\begin{array}{l}15(83.3) \\
12(66.6) \\
11(61.1) \\
7(38.8) \\
7(38.8) \\
5(27.7) \\
5(27.7) \\
3(16.6) \\
3(16.6) \\
2(11.1) \\
2(11.1) \\
2(11.1) \\
2(11.1) \\
1(5.5) \\
1(5.5)\end{array}$ \\
\hline CAM usage shared with doctor $(n: 18)$ & $\begin{array}{l}\text { Shared } \\
\text { Non-shared }\end{array}$ & $\begin{array}{l}15(83.3) \\
3(16.7)\end{array}$ \\
\hline Trust the effectiveness of CAM (n:18) & $\begin{array}{l}\text { Trust } \\
\text { Non-trust }\end{array}$ & $\begin{array}{l}8(44.4) \\
10(55.6)\end{array}$ \\
\hline Source knowledge of CAM usage ${ }^{*}(n: 18)$ & $\begin{array}{l}\text { TV/Radio } \\
\text { Family members } \\
\text { Friend } \\
\text { Doctor } \\
\text { Nurse } \\
\text { Book } \\
\text { Magazine } \\
\text { Internet }\end{array}$ & $\begin{array}{l}11(61.1) \\
3(16.6) \\
4(22.2) \\
7(38.8) \\
2(11.1) \\
2(11.1) \\
1(5.5) \\
2(11.1)\end{array}$ \\
\hline $\begin{array}{l}\text { Person recommending CAM method }{ }^{*} \\
(\mathrm{n}: 18)\end{array}$ & $\begin{array}{l}\text { Doctor } \\
\text { Nurse } \\
\text { Family members } \\
\text { By another OA patient } \\
\text { Neighbor }\end{array}$ & $\begin{array}{l}10(55.5) \\
5(27.7) \\
4(22.2) \\
3(16.6) \\
2(11.1)\end{array}$ \\
\hline
\end{tabular}

"More than one reply has been given.

The aim of OA treatment should be lessen the pain, protecting the joints, provide physical function independency and raising the quality of life. It order to reach the aims the $O A$ treatment should involve nonpharmalogical, pharmalogical and when needed, surgery meth- ods. The treatment should be applied to each patient in a special way. European League against Rheumatism (EULAR), Osteoarthritis Research Society International (OARSI) suggest in the effective OA treatment methods both the pharmalogical and non-pharmalogical combi- 
Table 3: The comparison between the demographic variables and the usage of CAM.

\begin{tabular}{|c|c|c|c|c|c|}
\hline \multirow{3}{*}{\multicolumn{2}{|c|}{ Demographic Variables }} & \multicolumn{4}{|l|}{ Usage of CAM } \\
\hline & & \multirow{2}{*}{$\begin{array}{l}\text { User } \\
\text { Frequency (\%) }\end{array}$} & \multirow{2}{*}{$\begin{array}{l}\text { Non-user } \\
\text { Frequency (\%) }\end{array}$} & \multirow{2}{*}{$\begin{array}{l}\text { TOTAL } \\
\text { Frequency (\%) }\end{array}$} & \multirow[b]{2}{*}{$\begin{array}{l}\text { Test } \\
\mathbf{X}^{2} p\end{array}$} \\
\hline & & & & & \\
\hline \multirow{2}{*}{ Gender } & Women & $15(83.3)$ & $46(77.6)$ & $61(78.9)$ & \multirow{2}{*}{$\begin{array}{l}X^{2}=0.241 \\
p=0.623\end{array}$} \\
\hline & Men & $3(16.7)$ & $13(22.4)$ & $16(21.1)$ & \\
\hline \multirow{5}{*}{ Age } & Under 30 & $0(0.0)$ & $3(5.1)$ & $3(3.9)$ & \multirow{5}{*}{$\begin{array}{l}X^{2}=4.724 \\
p=0.317\end{array}$} \\
\hline & 30-39 & $1(5.5)$ & $3(5.1)$ & $4(5.2)$ & \\
\hline & $40-49$ & $2(11.1)$ & $5(8.5)$ & $7(9.1)$ & \\
\hline & $50-59$ & $8(44.4)$ & $15(25.4)$ & $23(29.9)$ & \\
\hline & Over 60 & $7(38.9)$ & $33(55.9)$ & $40(51.9)$ & \\
\hline \multirow{3}{*}{ Maritual Status } & Married & $15(78.9)$ & $26(44.8)$ & $41(53.2)$ & \multirow{3}{*}{$\begin{array}{l}X^{2}=3.750 \\
p=0.153\end{array}$} \\
\hline & Bachelor & $0(0.0)$ & $3(5.2)$ & $3(3.9)$ & \\
\hline & Widowed & $4(21.1)$ & $29(50.0)$ & 33 (42.9) & \\
\hline \multirow{5}{*}{ Educational Status } & Illiterate & $2(10.5)$ & $3(5.2)$ & $5(6.5)$ & \multirow{5}{*}{$\begin{array}{l}X^{2}=9.442 \\
p=0.051\end{array}$} \\
\hline & Literate & $5(26.3)$ & $32(55.2)$ & $37(48.1)$ & \\
\hline & Primary school & $0(0.0)$ & $4(6.9)$ & $4(5.2)$ & \\
\hline & High school & $10(52.6)$ & $15(25.9)$ & $25(32.5)$ & \\
\hline & Graduate & $2(10.5)$ & $4(6.9)$ & $6(7.8)$ & \\
\hline \multirow{4}{*}{ Place of Birth } & City & $4(21.2)$ & $9(15.5)$ & $13(16.9)$ & \multirow{4}{*}{$\begin{array}{l}X^{2}=10.989 \\
p=\mathbf{0 . 0 1 2}\end{array}$} \\
\hline & Town & $10(52.6)$ & $12(20.7)$ & $22(28.6)$ & \\
\hline & Small Town & $1(5.3)$ & $14(24.1)$ & $15(19.5)$ & \\
\hline & Village & $4(21.1)$ & $23(39.7)$ & $27(65.1)$ & \\
\hline \multirow{3}{*}{ Income } & Low & $3(15.8)$ & $18(31.0)$ & $21(27.3)$ & \multirow{3}{*}{$\begin{array}{l}X^{2}=10.854 \\
p=\mathbf{0 . 0 0 4}\end{array}$} \\
\hline & Middle & $10(52.6)$ & $37(63.8)$ & $47(61.0)$ & \\
\hline & High & $6(31.6)$ & $3(5.2)$ & 9 (11.7) & \\
\hline \multirow{4}{*}{ Occupation } & Retired & $8(42.1)$ & $9(30.0)$ & $17(48.1)$ & \multirow{4}{*}{$\begin{array}{l}X^{2}=3.641 \\
p=0.303\end{array}$} \\
\hline & Government official & $4(21.1)$ & $4(6.9)$ & $8(10.4)$ & \\
\hline & Worker & $1(5.3)$ & $3(5.2)$ & $4(5.2)$ & \\
\hline & Housewife & $6(31.6)$ & $22(37.9)$ & $28(36.4)$ & \\
\hline
\end{tabular}

nation $[9,10]$. Getting no response in the conventional OA treatment makes way to new effective and confidential methods which leads patients more and more to use CAM applications. In the USA among patients using CAM rank place 6 with arthritis symptoms. Among those patients the percentage of OA patients is estimated to be high [5]. In a study made on patients with OA the prevalence of CAM use has been found $40 \%$ [11]. Likewise in a study made on South Australians the result of the CAM usage was $52.2 \%$ [12], in the USA $28 \%$ [13], in Spain the outcome was $65.5 \%$ [14]. In this study it has been found out that $23.4 \%$ of patients with OA have used CAM. At the end of this study it has been stated that the use of CAM has been lower compared to other studies and the reason for this has been that most patients shared their using CAM with doctors $(83.3 \%)$ and because of this doctors might have been effective in giving up the CAM usage.

The most commonly usage of CAM among patients with $\mathrm{OA}$ are stated as follows; herbals, massage, vitamins, energy therapy and homeopathy [15]. Zochling, et al. in his study stated that the OA patients in using CAM was commonly the use of vitamins [16]. Kaboli, et al. in his study stated that the OA patients in using CAM was commonly the use of prayers [13]. In the results of this study the outcomes of using CAM are respectively massage, diet, music, herbals and acupuncture.

The reason of the usage of massage applied by most patients with OA within the use of CAM methods might have been suggested by doctors and might have been applied to relieve the pains of patients.

Data on CAM can be obtained from different sources. The most important sources are mass media means. Araz, et al. and Algier, et al. reported their studies to obtain data of CAM to be respectively TV/ radio, books/magazine and newspaper $[17,18]$. In this study TV/radio have been the sources to have obtained data about CAM methods. This result has 
shown that the means of mass media have been effective in leading people to the usage of CAM methods and as a result of this in conveying the data it should be done professionally.

Today most patients use CAM in order to feel better [19]. The reasons of the usage of CAM within patients having cancer are firstly to contribute to the treatment, to prevent the reoccurance of the disease and as a last remedy [20]. The results of this study has shown similar outcomes with other studies which suggests the improvement of the condition concerning the disease.

It has been stated that CAM methods have been preferred mostly by women whereas the statistical outcomes don't show significant correlation between them [21-26], Kaboli, et al. [13] has stated in his study that women have used CAM commonly and pointed out that there is a significant correlation between the gender and CAM usage. In this study women have used CAM more than men and statistically the correlation is insignificant $(p>0.05)$.

In this study the results have shown that maritual status, birth place and income conditions in relation with the use of CAM have been statistically significant ( $p$ $>0.05$ ), gender, age, educational status and occupation in relation with the usage of CAM have been statistically insignificant $(p>0.05)$.

Most studies show that the usage of CAM has been among young patients more than compared to other ages [27-33]. In this study the usage of CAM covered the ages 50-59 and has been more compared to other age groups.

Looking at studies show that maritual status in relation with the use of CAM has been not statistically insignificant [34-36]. This study shows that among married people the CAM usage is the most.

There are studies which support the ineffective usage of CAM concerning the educational status $[24,37,38]$. There are also studies which show a significant correlation between the educational status and the usage of CAM and it is stated that the higher the educational status is the more the usage of CAM is $[22,23,26,39,40]$.

Studies different from these show that the lower the educational status is the more is the usage of CAM $[41,42]$. This study shows that high school graduates compared to other educational status groups were higher in using CAM.

In the studies which have been done the living place has not been effective on the usage of CAM $[24,38]$. Ceylan, et al. [40] has stated that the living place has been effective on the usage of CAM and more widespread among people living in cities. In this study the result shows that those born in towns have used CAM more in respect with the others.
In studies which have been done comparatively on the status of income and the usage of CAM have shown that the higher is the income the more is the usage of CAM $[23,26,40]$. In this study the result shows that the medium income status has used more CAM compared to the other income status.

\section{Conclusion}

The result of this study confirms that OA patients used CAM. At physical therapy polyclinics working nurses when receiving in service training CAM methods should be added to make nurses well equipped. It is also suggested that the staff working in health departments should follow and update researches based on facts including CAM methods and its effects.

\section{Limitation of the Study}

This study is limited with patients who applied at the physical therapy polyclinics at the Nevşehir i. Şevki Atasagun State Hospital.

\section{Acknowledgements}

We would like to thank the patients with OA admitted to the physical therapy polyclinics in this study for their participation and cooperation.

\section{Financial Support and Sponsorship}

None.

\section{Conflict of Interest}

The authors declared no conflicts of interest with respect to the authorship and/or publication of this article.

\section{References}

1. Tuncer T, Çay HF, Kaçar C, Altan L, Atik OŞ, Aydin AT, et al. (2012) Evidence-based recommendations for the management of knee osteoarthritis: A consensus report of the Turkish league against rheumatism. Turk J Rheumatol 27: 1-17.

2. Zhang Y, Jordan JM (2008) Epidemiology of osteoarthritis. Rheum Dis Clin North Am 34: 515-529.

3. Lawrence RC, Felson DT, Helmick CG, Arnold LM, Choi $\mathrm{H}$, et al. (2008) Estimates of the prevalence of arthritis and other rheumatic conditions in the United States. Part II. Arthritis Rheum 58: 26-35.

4. Kaçar C, Gilgil E, Urhan S, Arikan V, Dündar U, et al. (2005) The prevalence of symptomatic knee and distal interphlangeal joint osteoarthritis in the urban population of Antalya, Turkey. Rheumatol Int 25: 201-204.

5. Rannou F, Poiraudeau S (2010) Non-pharmacological approaches for the treatment of osteoarthritis. Best Pract Res Clin Rheumatol 24: 93-106.

6. Tokem Y (2006) The use of complementary and alternative treatment in patients with asthma. Tuberk Toraks 54: 189196.

7. Turan N, Öztürk A, Kaya N (2010) A new responsibility in nursing: Complementary therapy. Maltepe Üniversitesi Hemsirelik Bilim ve Sanati Dergisi 3: 93-97. 
8. Göker B (2001) Radiographic osteoarthritis of the hip joint in Turkey. Rheumatol Int 21: 94-96.

9. Kikuchi M, Matsuura K, Matsumoto $Y$, Inagaki T, Ueda R (2009) Bibliographical investigation of complementary alternative medicines for osteoarthritis and rheumatoid arthritis. Geriatr Gerontol Int 9: 29-40.

10. Zhang W, Nuki G, Moskowitz RW, Abramson S, Altman $R D$, et al. (2010) OARSI recommendations for the management of hip and knee osteoarthritis. Part III: changes in evidence following systematic cumulative update of research published through January 2009. Osteoarthritis Cartilage 18: 476-499.

11. Ernst E (2006) Complementary or alternative therapies for osteoarthritis. Nat Clin Pract Rheumatol 2: 74-80.

12. MacLennan AH, Myers SP, Taylor AW (2006) The continuing use of complementary and alternative medicine in South Australia: Costs and beliefs in 2004. Med J Aust 184: 27-31.

13. Kaboli PJ, Doebbeling BN, Saag KG, Rosenthal GE (2001) Use of complementary and alternative medicine by older patients with arthritis: A population-based study. Arthritis Rheum 45: 398-403.

14. Herman CJ, Dente JM, Allen P, Hunt WC (2006) Ethnic differences in the use of complementary and alternative therapies among adults with osteoarthritis. Prev Chronic Dis 3: 80.

15. Rao JK, Mihaliak K, Kroenke K, Bradley J, Tierney WM, et al. (1999) Use of complementary therapies for arthritis among patients of rheumatologists. Ann Intern Med 131: 409-416.

16. Zochling J, March L, Lapsley $\mathrm{H}$, Cross M, Tribe $\mathrm{K}$, et al. (2004) Use of complementary medicines for osteoarthritis A prospective study. Ann Rheum Dis 63: 549-554.

17. Araz A, Harlak H, Meşe G (2007) Health behaviors and alternative medicine use. The Turkish Armed Forces Preventive Medicine Bulletin 6: 112-122.

18. Algier LA, Hanoğlu Z, Özden G, Kara F (2005) The use of complementary and alternative (non-conventional) medicine in cancer patients in Turkey. Eur J Oncol Nurs 9: 138146.

19. Adams M, Jewell AP (2007) The use of complementary and alternative medicine by cancer patients. Int Semin Surg Oncol 4: 10.

20. Özçelik H, Fadillioğlu Ç (2009) Kanser hastalarının tamamlayıcı ve alternatif tedavi kullanım nedenleri. Türk Onkoloji Dergisi 24: 48-52.

21. Khalaf AJ, Whitford DL (2010) The use of complementary and alternative medicine by patients with diabetes mellitus in Bahrain: A cross-sectional study. BMC Complement Altern Med 10: 35.

22. Chang HY, Wallis M, Tiralongo E (2007) Use complementary and alternative medicine among people living with diabetes: Literature review. J Adv Nurs 58: 307-319.

23. Danneman K, Hecker W, Haberland H, Herbst A, Galler A, et al. (2008) Use of complementary and alternative medicine in children with type 1 diabetes mellitus - Prevalence, pattern of use, and costs. Pediatr Diabetes 9: 228-235.

24. Garrow D, Egede LE (2006) National patterns and correlates of complementary and alternative medicine use in adults with diabetes. J Altern Complement Med 12: 895-902.

25. Caballero LV, Morello CM, Chynoweth ME, Prieto-Rosinol A, Polonsky WH, et al. (2010) Ethnic differences in complementary and alternative medicine use among patients with diabetes. Complement Ther Med 18: 241-248.

26. Kumar D, Bajaj S, Mehrotra R (2006) Knowledge, attitude and practice of complementary and alternative medicines for diabetes. Public Health 120: 705-711.

27. Begbie SD, Kerestes ZL, Bell DR (1996) Patterns of alternative medicine use by cancer patients. Med J Aust 165: 545-548.

28. Burstein HJ, Gelber S, Guadagnoli E, Weeks JC (1999) Use of alternative medicine by women with early-stage breast cancer. N Engl J Med 340: 1733-1759.

29. Crocetti E, Crotti N, Feltrin A, Ponton P, Geddes M, et al. (1998) The use of complementary therapies by breast cancer patients attending conventional treatment. Eur J Cancer 34: 324-328.

30. Munstedt K, Kirsch K, Milch W, Sachsse S, Vahrson H (1996) Unconventional cancer therapy - Survey of patients with gynaecological malignancy. Arch Gynecol Obstet 258: 81-88.

31. Weis J, Bartsch HH, Hennies F, Rietschel M, Heim M, et al. (1998) Complementary medicine in cancer patients: Demand, patients' attitude, and psychological beliefs. Onkologie 21: 144-149.

32. Risberg T, Lund E, Wist E, Dahl O, Sundstrøm S, et al. (1995) The use of non-proven therapy among patients treated in Norwegian oncological departments: A cross-sectional national multicenter study. Eur J Cancer 31: 1785-1789.

33. Adler SR, Foskett JR (1999) Disclosing complementary and alternative medicine use in the medical encounter: $A$ qualitative study in women with breast cancer. J Fam Pract 48: 453-458.

34. Malik IA, Khan NA, Khan W (2000) Use of unconventional methods of therapy by cancer patients in Pakistan. Eur $\mathrm{J}$ Epidemio 16: 155-160.

35. Wolsko PM, Eisenberg DM, Davis RB, Kessler R, Phillips RS (2003) Patterns and perceptions of care for treatment of back and neck pain: Results of a national survey. Spine 28: 292-297.

36. Barnes PM, Griner EP, Mcfann K, Nahin RL (2004) Complementary and alternative medicine use among adults: United States, 2002. Seminars in Integrative Medicine 2: 54-71.

37. Tan M, Uzun Ö, Akçay F (2004) Trends in complementary and alternative medicine in Eastern Turkey. J Altern Complement Med 10: 861-865.

38. Haliloğlu B, İşgüven $P$, Yildiz $M$, Arslanoğlu I, Ergüven $M$ (2011) Complementary and alternative medicine in children with type 1 diabetes mellitus. J Clin Res Pediatr Endocrinol 3: 139-143.

39. Yeh GY, Eisenberg DM, Davis RB, Phillips RS (2002) Use of Complementary and alternative medicine among persons with diabetes mellitus: Results of a national survey. Am J Public Health 92: 1648-1652.

40. Ceylan S, Azal Ö, Taşlipinar A, Türker T, Açikel C, et al. (2009) Complementary and alternative medicine use among Turkish diabetes patients. Complement Ther Med 17: 78-83.

41. Al-Rowais NA (2002) Herbal medicine in the treatment of diabetes mellitus. Saudi Med J 23: 1327-1331.

42. Arykan D, Karaca SS, Olgun N (2009) Complementary alternative medicine use in children with type 1 diabetes mellitus in Erzurum, Turkey. J Clin Nurs 18: 2136-2144. 